\title{
Fractal dimension and geostatistical parameters for soil microrelief as a function of cumulative precipitation
}

\author{
Eva Vidal Vázquez¹; Sidney Rosa Vieira ${ }^{2 *}$; Isabella Clerici De Maria²; Antonio Paz \\ González ${ }^{1}$ \\ ${ }^{1}$ Universidade da Coruña (UDC) - Facultad de Ciencias, Campus de A Zapateira - 15071 A Coruña, Spain. \\ 2 Instituto Agronômico/IAC, Centro de Solos e Recursos Ambientais, Av. Barão de Itapura, 1481, C.P. 28 - \\ 13020-902 - Campinas, SP - Brasil. \\ *Corresponding author < sidney@iac.sp.gov.br>
}

\begin{abstract}
Surface roughness is influenced by type and intensity of soil tillage among other factors, and it changes considerably with rain. In microrelief studies the advantages of using indices such as the fractal dimension, $\mathrm{D}$, and the crossover length, 1 , is that they allow the partition of the roughness characteristics into properties that depend purely on the scale and on a scale free component, respectively. On the other hand, some geostatistical parameters may provide different ways to understand soil surface variability not addressed with fractal parameters. Changes in fractal dimension and semivariogram parameters for surface roughness evolution were evaluated as a function of cumulative rainfall on Oxisol samples over six tillage treatments, namely, disc harrow, disc plow, chisel plow, disc harrow + disc level, disc plow + disc level and chisel plow + disc level. Measurements were taken in each tillage treatment after rainfall events yielding a total of 48 experimental surfaces measured with a pin microrelief meter. The plot had $135 \mathrm{~cm}$ by $135 \mathrm{~cm}$ and the sample spacing was $25 \mathrm{~mm}$. Trends due to plot slope component with its concavities and convexities and to agricultural practices were removed from field data sets. A semivariogram model was fitted to each of the surfaces and the model parameters were analyzed and related to the fractal dimension, $\mathrm{D}$, and crossover length, $l$. A relationship was found between the fractal dimension, $\mathrm{D}$, and semivariogram model parameters. The cross over length, $l$, did not show as strong relationships with the semivariogram model parameters, even though there was a power relation between $\mathrm{D}$ and $l$.
\end{abstract}

Key words: Oxisol, tillage, soil surface roughness, semivariogram, crossover length

\section{Parâmetros fractais e geoestatística do microrrelevo do solo em função de chuva acumulada}

\begin{abstract}
RESUMO: A rugosidade da superfície pode ser influenciada pelo tipo e pela intensidade do preparo do solo entre outros fatores. A vantagem de se usar índices fractais em estudos de microrrelevo é que eles permitem a partição das características da rugosidade em propriedades ou que dependem exclusivamente da escala ou que independem totalmente dela. Por outro lado, a geoestatística prove algumas ferramentas que podem ser úteis no estudo da dinâmica da variabilidade da superfície do solo, diferentes daquelas avaliadas pela dimensão fractal. Verificou-se se é possível aplicar geoestatística na análise da variação do microrrelevo de um Latossolo sob seis tratamentos de preparo do solo, a saber: grade de discos, arado de discos, escarificador, grade de discos + grade niveladora, arado de discos + grade niveladora e escarificador + grade niveladora. As medidas foram feitas logo após o preparo do solo e subseqüentemente após cumulativos eventos de chuva natural. Medições duplicadas foram feitas em cada tratamento para cada data, produzindo um total de 48 superfícies. Um rugosímetro de agulhas foi utilizado para as medidas da rugosidade da superfície. A área de cada parcela era $1,35 \mathrm{~m}$ por $1,35 \mathrm{~m}$ e as medidas espaçadas de $0,25 \mathrm{~m}$, produzindo um total de 3025 pontos por parcela. Tendência devido à inclinação do terreno e causadas pelo preparo do solo foi removida dos dados experimentais. Foram ajustados modelos aos semivariogramas de cada superfície e os parâmetros desses modelos analisados e relacionados aos parâmetros de dimensão fractal. Foi encontrada relação entre a dimensão fractal, D, e os parâmetros dos modelos dos semivariogramas. O parâmetro de auto-afinidade, $l$, não mostrou relação forte com parâmetros dos modelos dos semivariogramas apesar de ter tido uma relação de potência entre $\mathrm{D}$ e $l$.
\end{abstract}

Palavras-chave: Latossolo, preparo do solo, rugosidade da superfície do solo, semivariograma, índices de rugosidade

\section{Introduction}

There are many ways in which the soil surface roughness may be changed with natural or imposed causes. Soil tillage may modify surface roughness by breaking large clods into smaller ones and by introducing mounds, rips and furrows. The amount of rainfall that reaches an uncovered soil surface may also be an important factor that can cause changes in its roughness. Usually the roughness left by tillage will smooth out as 
the rainfall amount increases. Soil microrelief has been defined as a set of topographical characteristics of an area of interest at a millimetric or centimetric scale (Allmaras et al., 1966; Currence \& Lovely, 1970; Huang, 1998), consisting of distances from the soil surface to an arbitrary plane, which can be measured with a laser scanner or with a pin meter, respectively (Allmaras et al., 1966; Linden and Doren, 1986; Huang and Bradford, 1992).

Vidal Vázquez et al. (2005) presented a very detailed analysis of surface roughness with fractal parameters. Two fractal parameters, fractal dimension, $\mathrm{D}$, which describes how roughness changes with scale, and crossover length, $l$, specifying the variance of surface microrelief at a reference scale, have also been used for assessing soil surface microrelief. According to Vidal Vázquez et al. (2006) D and $l$ can be determined using the slope of a $\log$-log relationship of the semivariogram and the corresponding Y-axis intercept. Fractal indices can reveal important characteristics of the surface roughness in relation with the size of grains or clods (Su et al., 2004).

Geostatistical analysis of spatial variability has been extensively used and documented at different scales (Vieira et al., 1983; Paz González et al., 2000), including soil surface microrelief plots characterized by point elevation measurements (Vidal Vázquez et al., 2005; Vidal Vázquez et al., 2008). Through the analysis of the parameters of the semivariogram models fitted to different data sets it is possible to assess the similarity between them or to compare their variability (Vieira et al., 2002).

The objective of this study was to evaluate the changes in fractal dimension and semivariogram parameters for surface roughness evolution as a function of $\mathrm{cu}-$ mulative rainfall.

\section{Material and Methods}

The field measurements for the present study were obtained in Campinas, state of São Paulo, Brazil (22 ${ }^{\circ} 53^{\prime}$ ', $47^{\circ} 04^{\prime} \mathrm{W}$, near $600 \mathrm{~m}$ asl). The soil was a Rhodic Eutrustox (Soil Survey Staff, 2006), corresponding to a Latossolo Vermelho Eutroférrico tipico (Oliveira et al., 1989), according to the Brazilian Soil Classification System.

The surface roughness measurements were made between October and November 2000, at a site in which the slope was $5.1 \%$. A total of 48 measurements were made corresponding to six tillage treatments over four dates, immediately after tillage and after three cumulative rainfalls in two duplicate measurements per treatment. The three primary tillage treatments studied were disc plow (DP), disc harrow (DH) and chisel plow (CP), with cumulative natural rains of $0,24.4,113.3$ and 232.8 for disc plow, 0, 24.4, 120.9 and 232.8 for disc harrow and chisel plow. Besides these, disc plow plus leveling disc $(\mathrm{DP}+\mathrm{LD})$, disc harrow plus leveling disc $(\mathrm{DH}+\mathrm{LD})$, chisel plow plus leveling disc $(\mathrm{CP}+\mathrm{LD})$ with cumulative natural rains of 0, 24.4, 232.8 and $294.6 \mathrm{~mm}$ were also assessed. Table 1 summarizes the tillage treatments and cumulative rainfalls before each surface roughness was measured. Two sets of measurements were taken for each combination of tillage treatment and cumulative rainfall.

The surface roughness measurements were taken with a pin microrelief meter as described in Vidal Vázquez et al. (2008). The plot area was $135 \mathrm{~cm}$ by 135 $\mathrm{cm}$ and the sample spacing was $25 \mathrm{~mm}$, yielding a total of 3025 data points per measurement.

Because surface roughness heights showed some trend, the surface height data were submitted to a trend removal technique which involves the subtraction of a three dimensional surface fitted by minimum least squares from the original data, with a degree 1, 2 or 3 , depending on the goodness of fit produced and the resulting semivariogram. This technique is well described in Vieira (2000). The primary objective of the trend removal in microrelief analysis is to obtain the surface roughness without the slope and tillage components (Currency and Lovely, 1970). However, in this study the trend was removed by best fit techniques and the aim was to produce an intrinsic semivariogram with a well defined sill.

Geostatistical data treatment comprised the analysis of semivariograms with their respective parameters of models fitted according to Vieira et al. (1983). Semivariograms are calculated using:

$\gamma(h)=\frac{1}{2 N(h)} \sum_{i=1}^{N(h)}\left[Z\left(x_{i}\right)-Z\left(x_{i}+h\right)\right]^{2}$

where $\mathrm{N}(\mathrm{h})$ is the number of pairs of height values, $Z(x)$ separated by a vector $b$. The experimental semivariograms were all quite adequately fitted to the exponential model, which were validated with the jack knifing procedure according to Vieira (2000). The expo-

Table 1 - Tillage treatments and respective cumulative rainfall $(\mathrm{mm})$ before each microrelief measurement with the pin microrelief meter.

\begin{tabular}{cccccc}
\hline \multicolumn{5}{c}{ Tillage treatment } \\
\hline Disc plow & Disc harrow & Chisel plow & $\begin{array}{c}\text { Disc plow }+ \\
\text { leveling disk }\end{array}$ & $\begin{array}{c}\text { Disc harrow }+ \\
\text { leveling disc }\end{array}$ & $\begin{array}{c}\text { Chisel plow }+ \\
\text { leveling disc }\end{array}$ \\
\hline 0 & 0 & 0 & 0 & 0 & 0 \\
24.4 & 24.4 & 24.4 & 24.4 & 24.4 & 24.4 \\
113.8 & 120.9 & 120.9 & 232.8 & 232.8 & 232.8 \\
232.8 & 232.8 & 232.8 & 294.6 & 294.6 & 294.6 \\
\hline
\end{tabular}

Sci. Agric. (Piracicaba, Braz.), v.67, n.1, p.78-83, January/February 2010 
nential model fitted follows the equation:

$\gamma(h)=C_{0}+C_{1}\left[1-\operatorname{EXP}\left(-\frac{h}{a}\right)\right]$

where $C_{0}, C_{1}$ and $a$ are, respectively, the nugget effect, the structural variance and the range of spatial dependence.

Accurate description of soil surface topography by fractal analysis relies on estimation of two fractal indices, fractal dimension, $\mathrm{D}$, which describes how roughness changes with scale, and crossover length, $l$, specifying the variance of surface microrelief at a reference scale (Vidal Vázquez et al., 2008). Historically, seminal work of Mandelbrot (1983) first related semivariogram and fractal dimension. In this paper, the evolution of the fractal and semivariogram parameters as a function of the cumulative rainfall is evaluated as they may characterize different descriptions for the rainfall smoothing effect on surface roughness. For a fractal transect the semivariogram, follows the equation:

$\gamma(b)=\mathrm{K} b^{2 \mathrm{H}}$

where the exponent of the incremental function, $\mathrm{H}$, is the Hurst exponent. The power model which describes a self-similar fractal corresponds to a phenomenon with an unlimited capacity for spatial dispersion and with an undefined a priori variance.

Assuming a fractal Brownian motion ( $\mathrm{fBm}$ ) model, the Hurst exponent, $H$, is allowed to vary from 0 to 1 (Huang and Bradford, 1992). In this case, the log-log behavior of the semivariogram may be described as a function of the crossover length, $l$, and the Hurst exponent, $\mathrm{H}$, as:

$\gamma(b)=l^{1 " H} b^{H}$

Thus, the fractal dimension of a fractal surface or profile represented by its semivariogram can be estimated by examining the slope of the semivariance, $\tilde{a}(b)$, versus the lag distance, $b$, when plotted on a double logarithmic scale. Once the Hurst exponent, $H$, is obtained by Eq. (5), the fractal dimension, $D$, of a soil surface is computed from these and the Euclidean dimension $(d=3)$ as:

$D=3-H$

Finally, as described by Huang and Bradford (1992), the crossover length, $l$, may be estimated by:

$l=\exp [(a / 2-2 \mathrm{H})]$

The advantage of using indices such as the fractal dimension, $\mathrm{D}$, and the crossover length, $l$, is that they may be a very consistent way of measuring the surface roughness regardless of the numerical value for their magnitude (Vidal Vázquez et al., 2008). Therefore, the fractal analysis parameters together with the semivariogram parameters can be adequate for the characterization of the surface roughness independent of the scale of the measurements. The parameters of the semivariograms and the roughness indices were analyzed for all surfaces as a function of cumulative natural rainfall in order to assess the dynamics of the surface roughness as the rainfall increases.

\section{Results and Discussion}

Figures $1 \mathrm{a}$ and $1 \mathrm{~b}$ show the relationship between the fractal dimension, D, and Figures $2 \mathrm{a}$ and $2 \mathrm{~b}$ the crossover length, $l$, as a function of the cumulative rainfall and tillage treatment. Analysis of variance was made on both $\mathrm{D}$ and $l$, revealing that the values for the crossover length $l$, were not statistically different for all treatments. The fractal dimension $\mathrm{D}$ was significantly different for $\mathrm{CP}$ treatment and not significant for the other treatments.

The fractal dimension, $\mathrm{D}$, seem to be less sensitive than the cross over the length, $l$, to the increase in cumulative rainfall. The smallest values for $\mathrm{D}$ were found for the tillage treatment CP (Figure 1a and 1b) with the values ranging around 2.5. Regardless of tillage treatment or cumulative rainfall, it is apparent that these two fractal parameters, D and $l$, seem to be somewhat related, as a change in one of them is, in general, followed by a proportional change on the other one. In general both, $\mathrm{D}$ and $l$, decrease as the cumulative rainfall increase. The cross over length parameter, $l$, in general, decreases steadily as the cumulative rainfall increase, and stabilizes at values between 5 and 10 (Figures 2a and $2 b)$. For this parameter, the lowest values also occur for chisel plow (CP) treatment (Figure 1a). This may be another reason to consider a deeper study of the trend removal technique as it may affect the resulting surface roughness and consequently, its fractal parameters.

Results indicate a larger variation in scale of the crossover length, $l$, when compared with the fractal dimension, D (Figures 1 and 2). This reinforces the relevancy of the crossover length parameter, $l$, as a discriminator of vertical differences in roughness. In surface roughness quantification the fractal dimension, D, can be taken as a relative measure of the distribution of different sized structural elements on the soil surface (Huang, 1998). In this context, fractal dimension is a descriptor of horizontal variations of soil roughness, which implies that it has to be considered in connection with an index describing differences in roughness height (Huang 1998; Vidal Vázquez et al., 2006).

To illustrate better the relationship between the fractal dimension, $\mathrm{D}$, and the crossover length, $l$, a correlation was calculated and plotted in Figure 3. The power equation fitted to the relationship between $\mathrm{D}$ and $l$ (Figure 3) represents an expected result from equation (6).

The relationship between $\mathrm{D}$ and $l$ as a function of the tillage treatments also shows that the use of the leveling harrow (treatments named LD) separated these two parameters in two different classes, in which the treatments that received the leveling harrow always had a 

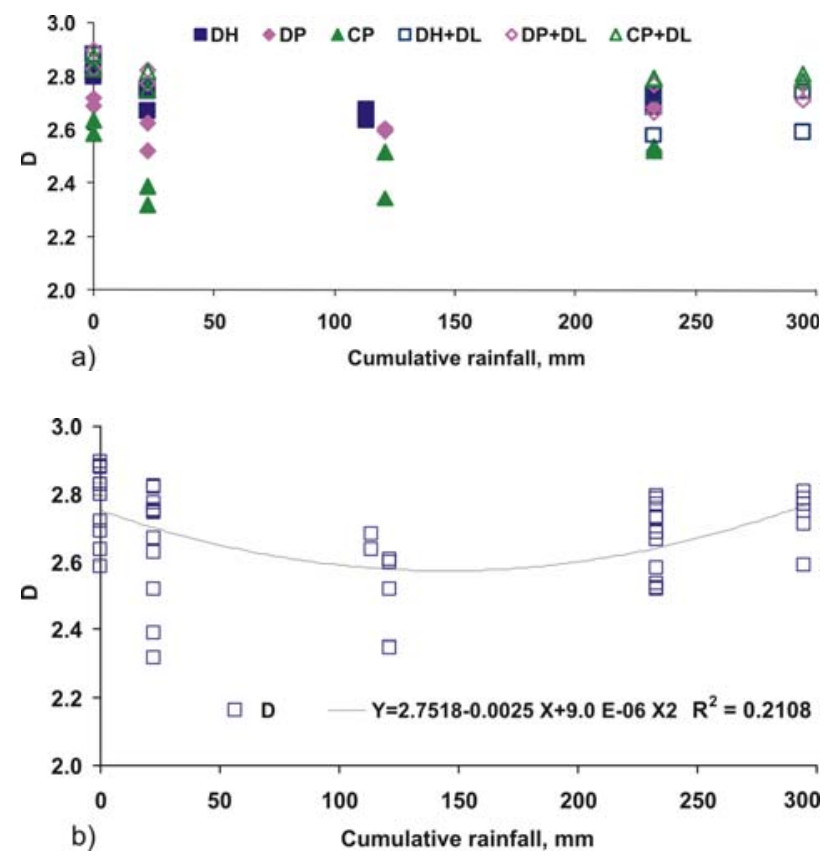

Figure 1 - Relationship between fractal dimension, D, and cumulative rainfall for all tillage treatments. $\mathrm{DH}=$ disc harrow, $\mathrm{DP}=$ disc plow, $\mathrm{CP}=$ chisel plow, $\mathrm{DH}+\mathrm{DL}=$ disc harrow + disc level, $\mathrm{DP}+\mathrm{DL}=$ disc plow + disc level, $\mathrm{CP}+\mathrm{DL}=$ chisel plow + disc level.

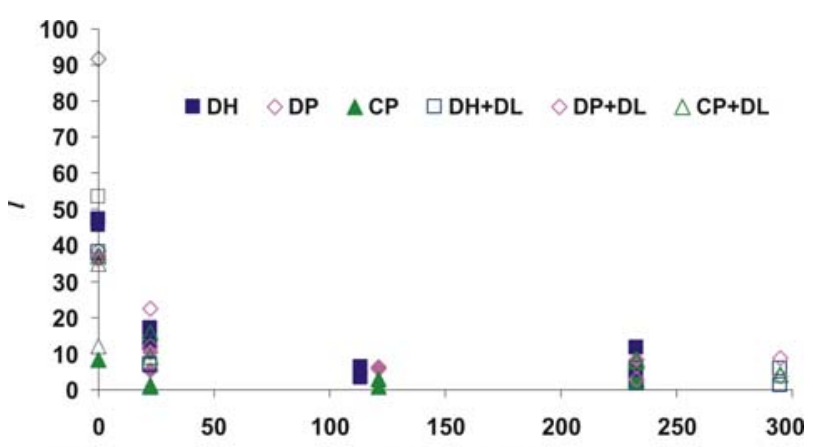

a)

Cumulative rainfall, $\mathrm{mm}$

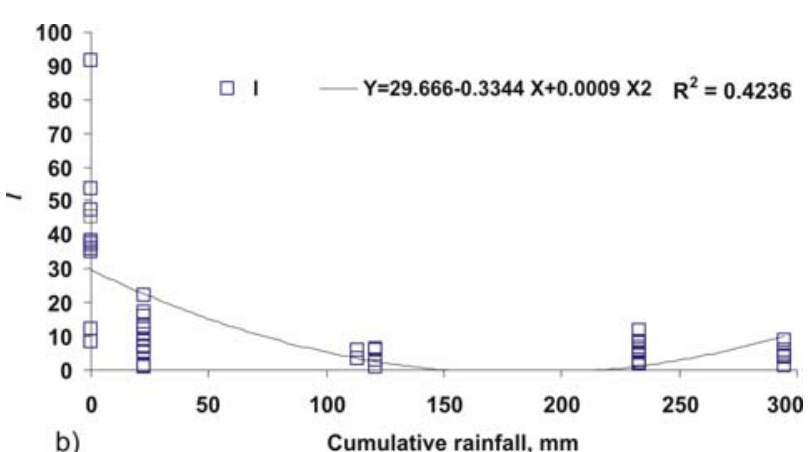

Figure 2 - Relationship between crossover length, $l$, and cumulative rainfall for all tillage treatments. $\mathrm{DH}=$ disc harrow, $\mathrm{DP}=$ disc plow, $\mathrm{CP}=$ chisel plow, $\mathrm{DH}+\mathrm{DL}=$ disc harrow + disc level, $\mathrm{DP}+\mathrm{DL}=$ disc plow + disc level, $\mathrm{CP}+\mathrm{DL}=$ chisel plow + disc level. larger fractal D for the same value of $l$. Firstly, higher values of $\mathrm{D}$ indicate a more rugged surface, with variation occurring mostly at a fine scale. Secondly, the use of the secondary tillage implement provided an approximately linear relationship between $\mathrm{D}$ and $l$. Therefore, the power law relationship between $\mathrm{D}$ and $l$ may be only particularly true for the surfaces that have tillage marks on their roughness.

As the random roughness parameter, RR, suggested by Allmaras et al. (1966) is simply the standard deviation of the heights, Figure 4 presents the relation between the fractal dimension $\mathrm{D}$ and the cross over length $l$ and the surface height variances. The fractal dimension $\mathrm{D}$ tends to decrease as the variance value increases (Figure 4a). Moreover, the smallest values for variance are the ones corresponding to the plots that received a secondary tillage. The reason why these values are grouped

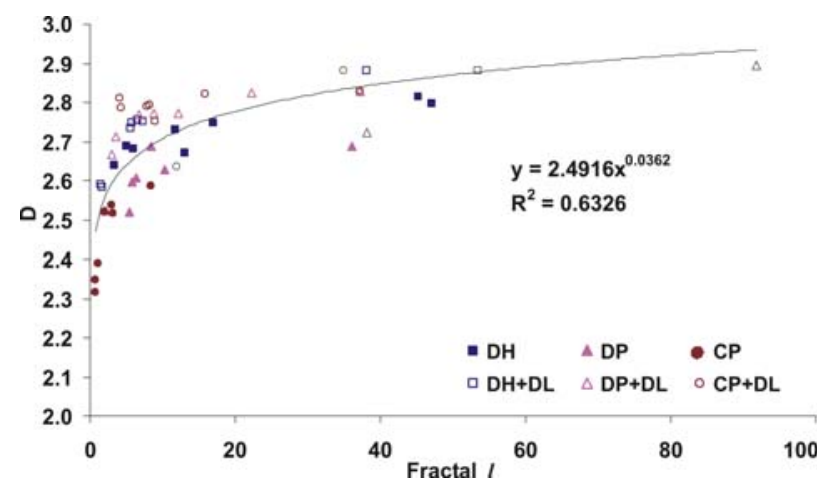

Figure 3 - Relationship between fractal dimension, D, and crossover length, $l$.

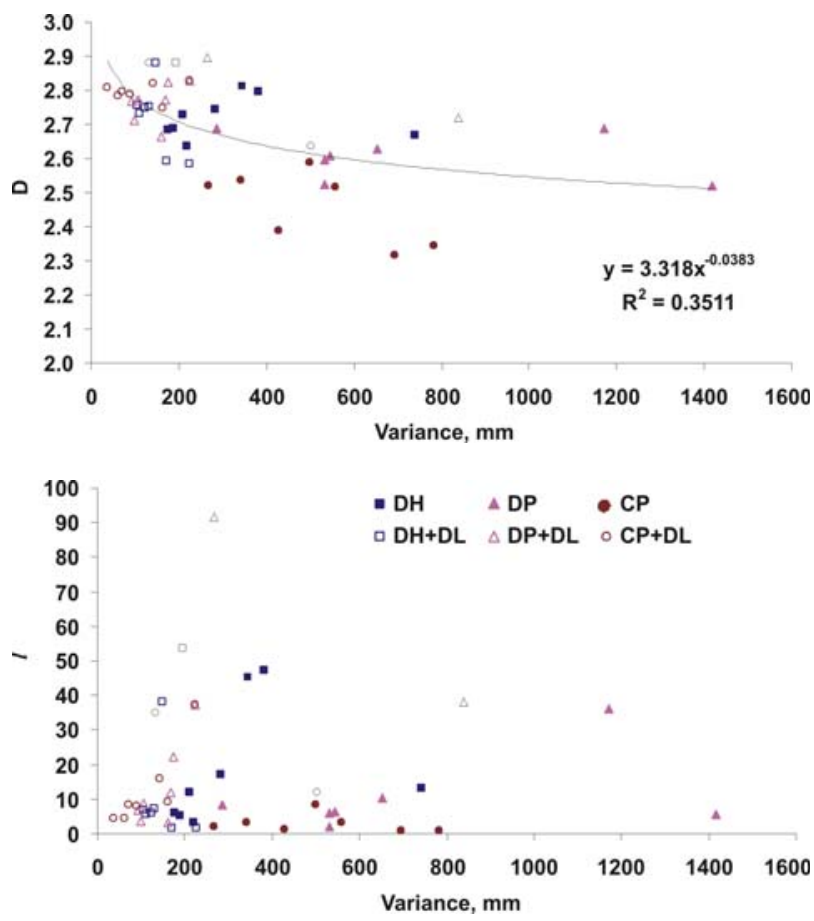

Figure 4 - Relationship between fractal dimension, D, and crossover length, $l$, and variance. 
together is that the surfaces that did not receive the secondary tillage, in general, tend to present more tillage marks than the ones that did receive the leveling harrow as a secondary tillage. The highest values for variance and consequently, lowest for fractal D, are for the surfaces corresponding to tillage treatments, which move more soil such as the chisel plow (CP) and disk plow (DP). The relation between the crossover length and the variance (Figure $4 \mathrm{~b}$ ) is not so clear. Because these parameters depend on the technique used to remove the trend, the results found here represent a different surface and cannot be compared with the ones presented by Vidal Vázquez et al. (2006).

Figures 5 and 6 illustrate relations between the semivariogram model parameters and the fractal dimension, $\mathrm{D}$, and the cross over length, $l$. The range of the semivariogram model represents the average size of areas within which the values are more similar to each other than at larger distances. As the soil surface roughness tends to smooth out as a function of cumulative rainfall, the range of the semivariogram may change accordingly. On the other hand, Bertolani et al. (2000) did not find changes in spatial dependence of surface roughness with the application of different amounts of rain. Therefore, the range of the semivariogram model is also an important parameter in the representation of the relative height of the surface. The fractal dimension $\mathrm{D}$ has a relation with the range of the semivariograms, as the values of the fractal dimension $\mathrm{D}$ increase with values of the range of the semivariograms (Figure 5). The increase in the $\mathrm{D}$ value only happens at range values below approximately $300 \mathrm{~mm}$, where the $\mathrm{D}$ values stabilize in ap-

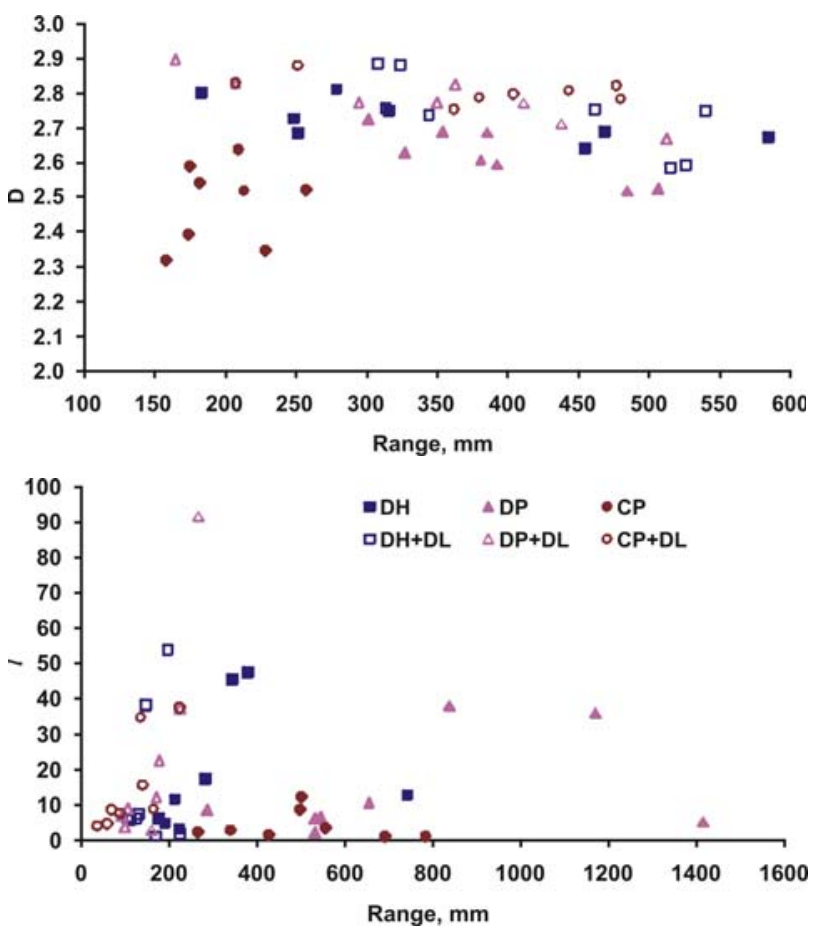

Figure 5 - Relationship between fractal dimension, D, crossover length, $l$ and range of spatial dependence. proximately 2.8 . Therefore, it is possible that the relation between $\mathrm{D}$ and the range of the semivariogram will be stronger for surfaces that were not yet smoothed out by cumulative rainfall. The crossover length, $l$, does not have any relation with the range of the semivariograms.

The linear relationship between the fractal dimension, $\mathrm{D}$, and the crossover length, $l$, and the nugget effect value (Figure 6a) is much more due to the smoother surfaces that received a leveling harrow than the surfaces that still presented signs of the tillage tool. Figure $6 \mathrm{~b}$ shows a linear relation between the cross over length $l$, and the nugget effect value with a coefficient of determination of 0.5498 . However, this relation is greatly caused by surfaces which received the leveling harrow as a secondary tillage tool as the values corresponding to the treatments that received a leveling disk (LD) are all very close to the regression line in Figure $6 \mathrm{~b}$.

The fractal analysis parameters together with the geostatistical analysis parameters can help in the understanding of the surface roughness independent of the scale of the measurements. On the other hand, the technique used to remove trends may need further and deeper studies as it affects the relations between different parameters that express surface roughness.

\section{Conclusions}

The trend removing method affected both the geostatistical and fractal indices' results. Geostatistical analysis may help in characterizing soil surface microrelief features as it provides additional insight into the assessment obtained from currently used roughness indices. There is a relationship between the fractal di-

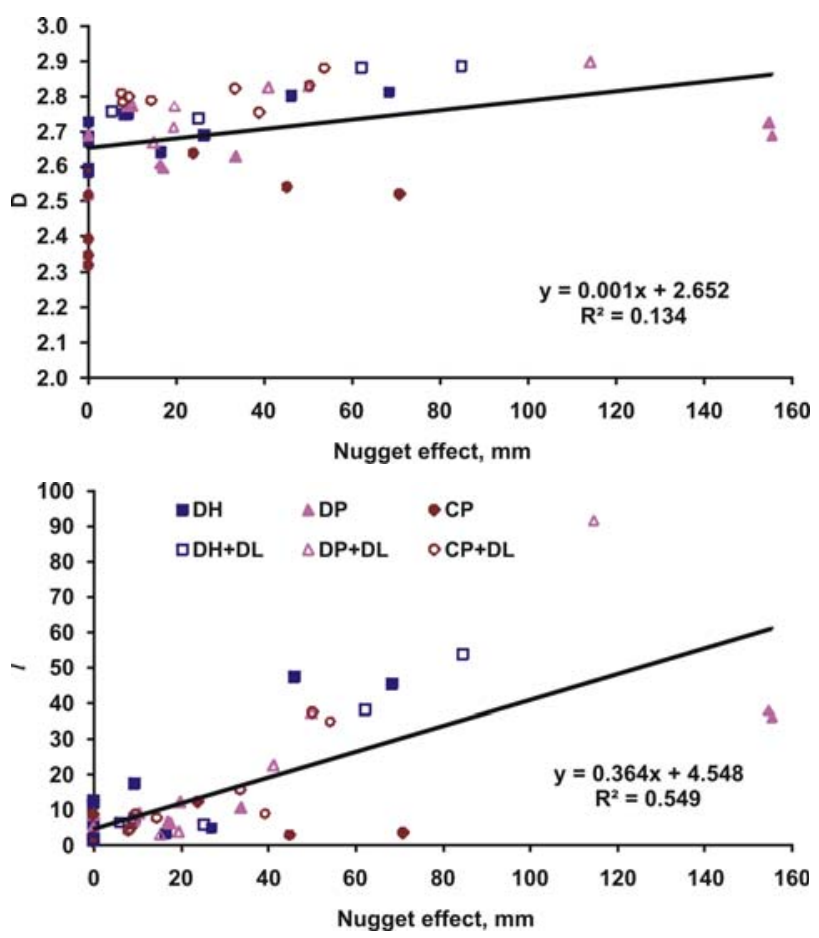

Figure 6 - Relationship between fractal dimension, D, and crossover length, $l$, and nugget effect values. 
mension, D, and semivariogram model parameters nugget effect and the range of dependence, and it is affected by the amount of cumulative rainfall. The crossover length, $l$, was only related to the semivariogram parameter that characterizes small scale variability (nugget effect) but had no relation with the range of spatial dependence as it is a measure of the large scale variability.

\section{Acknowledgments}

This work was partly performed in the frame of the following research projects: PHB 2003-0043-PC, financed by CAPES (Brazil) and MEC (Spain) and CGL200508219-C02/HID financed by I+D National Program on Biodiversity Earth Sciences and Global Change (CGL), subprogram HID of MEC (Spain).

\section{References}

Allmaras, R.R.; Burwell, R.E.; Larson, W.E.; Holt, R.F. 1966. Total Porosity and Random Roughness of the Interrow Zone as Influenced by Tillage. USDA, Washington, D.C., USA.

Bertolani, F.C.; Paz González, A.; Lado Liñares, M.; Vidal Vázquez, E.V.; Vivas Miranda. J.G. 2000. Variabilidade espacial da rugosidade superficial do solo medida com rugosímetros de agulhas e laser. Bragantia 59: 227-234.

Currence, H.D.; Lovely, W.G. 1970. The analysis of soil surface roughness. Transactions of the American Society of Agricultural Engineering 13: 710-714.

Huang, C. 1998. Quantification of Soil Microtopography and Surface Roughness. p.153-168. In: Baveye, P.; Parlange, J.Y.; Stewart, B.A., eds. Fractals in Soil Science. CRC Press, Boca Raton, FL, USA.

Huang, C.; Bradford, J.M. 1992. Applications of a laser scanner to quantity soil microtopography. Soil Science Society of America Journal 56: 14-21.

Linden, D.R.; Doren, D.M. van. 1986. Parameters for characterizing tillage induced soil surface roughness. Soil Science Society of America Journal 50: 1560-1565.
Mandelbrot, B.B. 1982. The Fractal Geometry on Nature. Freeman, San Francisco, CA, USA.

Oliveira, J.B.; Menk, J.R.F.; Rotta, C.L. 1979. Levantamento Pedológico Semidetalhado dos Solos do Estado de São Paulo: Quadrícula de Campinas. IBGE, Rio de Janeiro, RJ, Brasil.

Paz González, A.; Vieira, S.R.; Taboada Castro, M.T. 2000. The effect of cultivation on the spatial variability of selected properties of an umbric horizon. Geoderma 97: 273-292.

Soil Survey Staff. Keys to Soil Taxonomy. 2006. 10 ed. Natural Resources Conservation Service. USDA, Washington, D.C., USA.

Su, Y.Z., Zhao, H.L., Zhao, W.Z.; Zhang, T.H. 2004. Fractal features of soil particle size distribution and the implication for indicating desertification. Geoderma 122: 43-49.

Vidal Vázquez, E.; Miranda, J.G.V.; Alves, M.C.; Paz González, A. Effect of tillage indices describing soil surface microrelief of a Brazilian Alfisol. 2006. Geoderma 134: 428-439.

Vidal Vázquez, E.; Miranda, J.G.V.; Alves, M.C.; Paz González, A. 2005. Characterizing anisotropy and heterogeneity of soil surface microtopography using fractal models. Ecological Modelling 182: 337-353.

Vidal Vázquez, E.; Vieira, S.R.; De Maria, I.C.; Paz González, A. 2009. Geostatistical analysis of microrelief of an Oxisol as a function of tillage and cumulative rainfall. Scientia Agricola 66: 225-232.

Vieira, S.R. 2000. Geoestatística em estudos de variabilidade espacial do solo. v.1, p.1-54. In: Novais, R.F.; Alvarez, V.H.; Schaefer, G.R., eds. Tópicos em ciência do solo. Sociedade Brasileira de Ciência do Solo, Viçosa, MG, Brasil.

Vieira, S.R.; Hatfield, J.L.; Nielsen, D.R.; Biggar, J.W. 1983. Geostatistical theory and application to variability of some agronomical properties. Hilgardia 51:1-75.

Vieira, S.R.; Millete, J.; Topp, G.C.; Reynolds, W.D. 2002. Handbook for geostatistical analysis of variability in soil and climate data. v.2, p.1-45. In: Alvarez, V.H.; Schaefer, C.E.G.R.; Barros, N.F.; Mello, J.W.V.; Costa, L.M., eds. Tópicos em ciência do solo. Sociedade Brasileira de Ciência do Solo, Viçosa, MG, Brasil.

Received March 16, 2007

Accepted August 21, 2009 